\title{
RECONSTRUCTING SANDSTONE PROVENANCE: WHAT IS THE WITHIN-CATEGORY VARIANCE OF INDICATORS?
}

\author{
J. Barry Maynard and Paul Edwin Potter \\ University of Cincinnati \\ Cincinnati OH USA
}
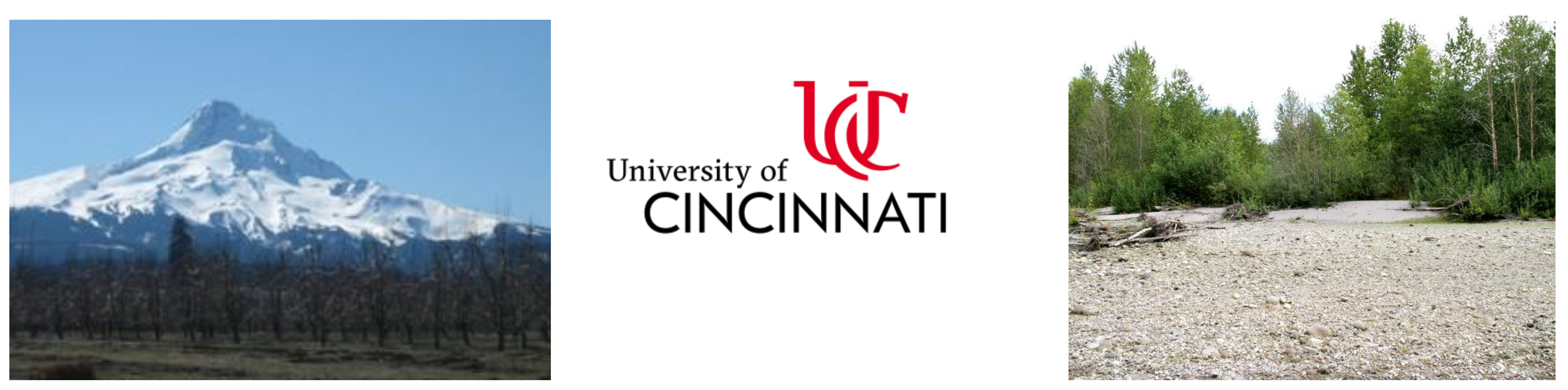


\section{The Issue}

When confronted with a sandstone, one of the first questions we ask it is

"What was your tectonic setting?"

The rock responds with a new question: "Do you mean of the source rocks or do you mean of the basin of deposition?"

Now we are in trouble. Imagine the Andes, sending sediments westward into a fore-arc basin and eastwards into a passive margin setting.

Two ways of looking at tectonics and sand composition.

The Dickinson model emphasizes tectonics of the source. What I would call the Valloni model (Valloni and Maynard 1981) emphasizes the tectonics of the sink.

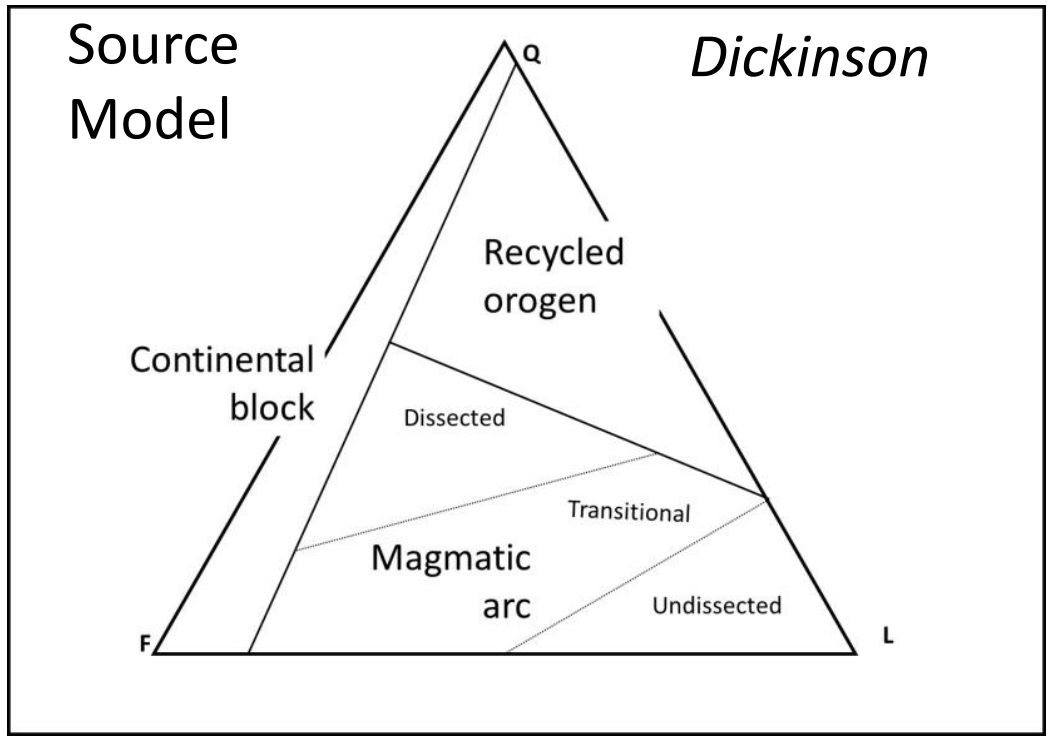


Our sandstone is asking us to be more specific; our response will depend on our aim.

A. We are reconstructing the unroofing history a batholith: then clearly we want to deploy the source model

B. We are modeling subsidence of a basin and want the timing of thrust loading: then we might deploy the sink model

\section{BUT}

A. The source model is based on ancient sediments on the continents and so interpretation is clouded by diagenetic overprints and lack of island arc provenance representatives

B. The sink model, although based on unlithified sediments, uses deep-sea sands and has no information on rifts, which is a critical setting for mineral deposits

C. Both models use rather subjective assignments of samples to categories and we don't know the within-category $v$. between-category variance of the parameters

so

We need to look at modern sands from many settings and test assignments to categories statistically 


\section{"Not so fast!" Our}

sandstone tells us. "How do you run ANOVA on a triangular plot with constant-sum and nonnegativity constraints."

An annoying critic is our rock, but surely it has something important to say to us, if only we listen carefully.

PEP conversing with a BereaSunbury exposure

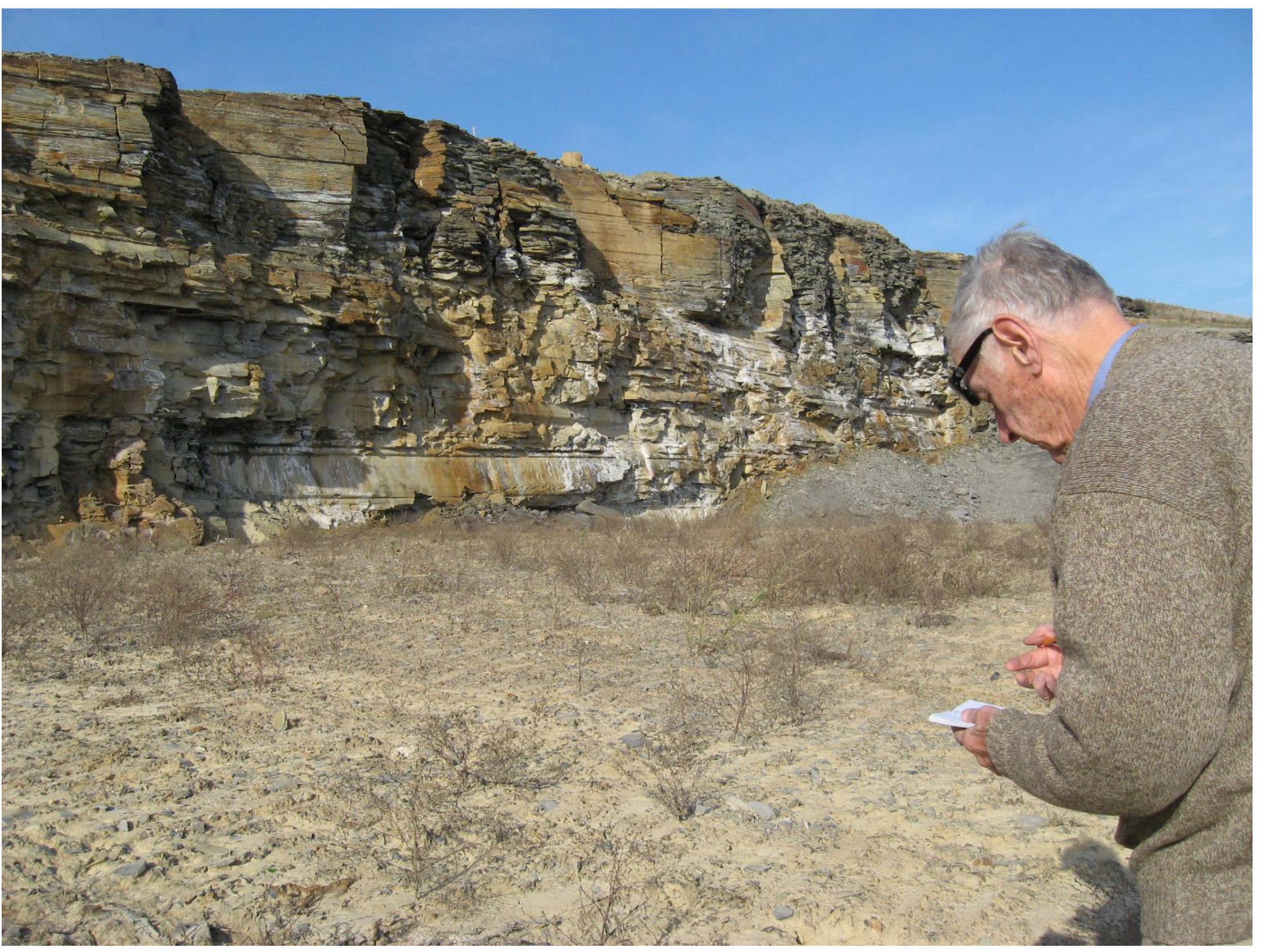




\section{Tactics}

1. Study smaller streams from obvious sources - source and sink have same setting; no diagenetic overprint; objective assignments of categories

2. Transform petrographic variables to log ratios (Weltje 2002, 2006)

3. Supplement petrographic data with chemical data

4. Do single-mineral grain studies (feldspars, magnetite, garnet, zircons)

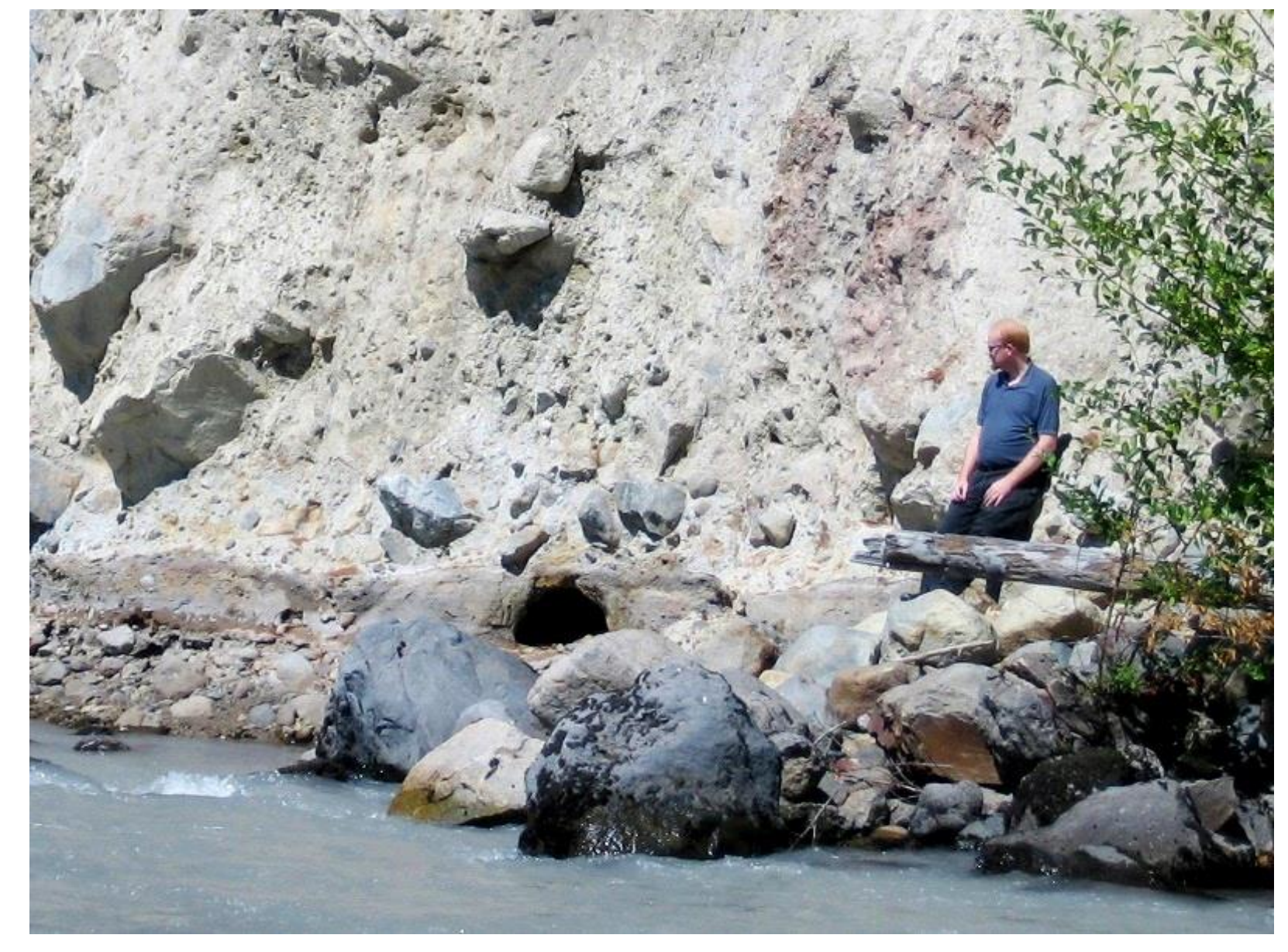

Lahar exposed in White River, Mt Rainier. Much of the stream sand is likely recycled from lahars. 


\section{Study Area - Location}

Streams draining Cascade volcanoes in Washington and adjacent Oregon, south of continental glacial limit.
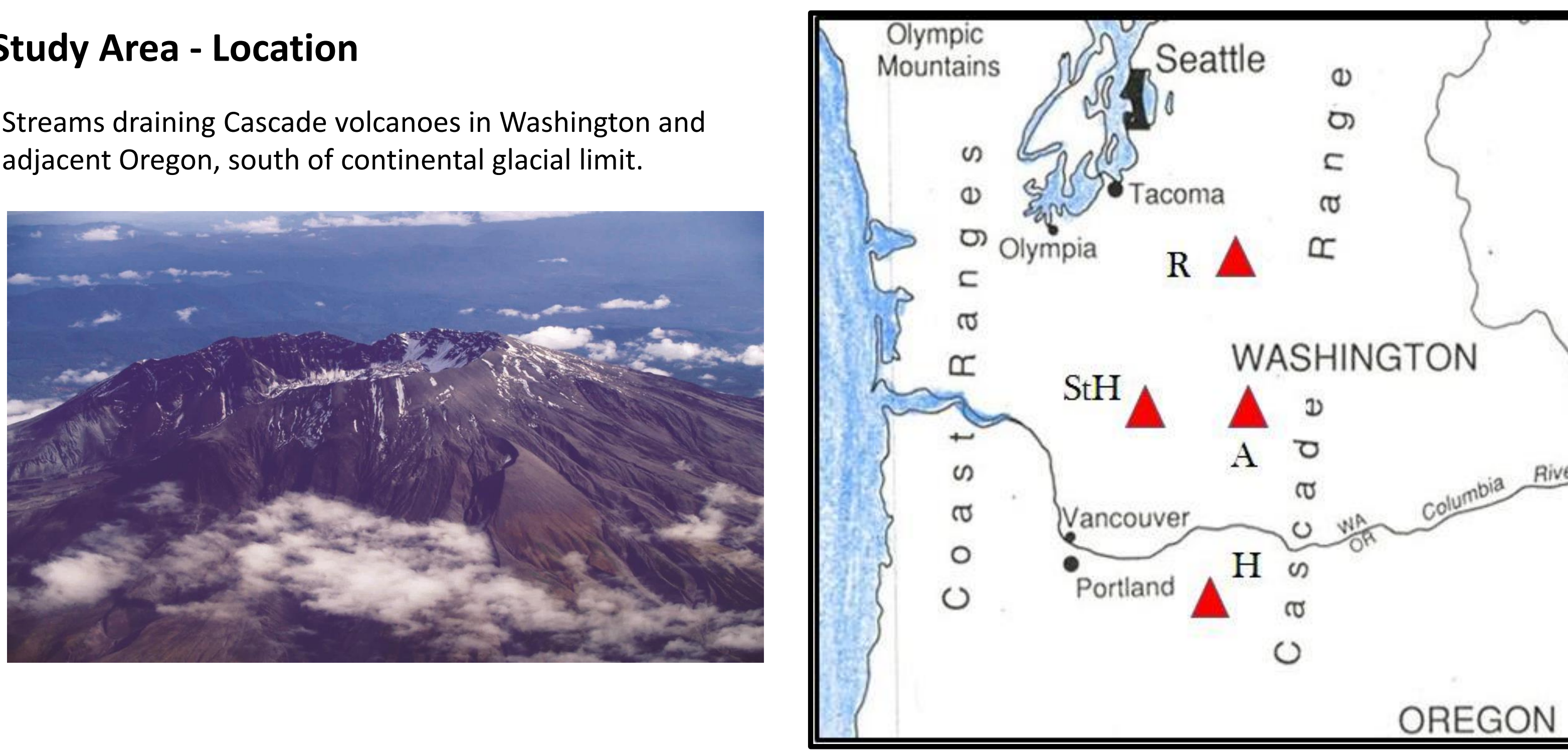


\section{Study Area - Classification}

Source Model: From Ingersoll et al. (1993) the area is mostly undissected magmatic arc with some areas of exposed older rocks, which would belong to the transitional category.

Sink Model: A magmatic arc on continental crust and hence a continent-margin arc (CA).
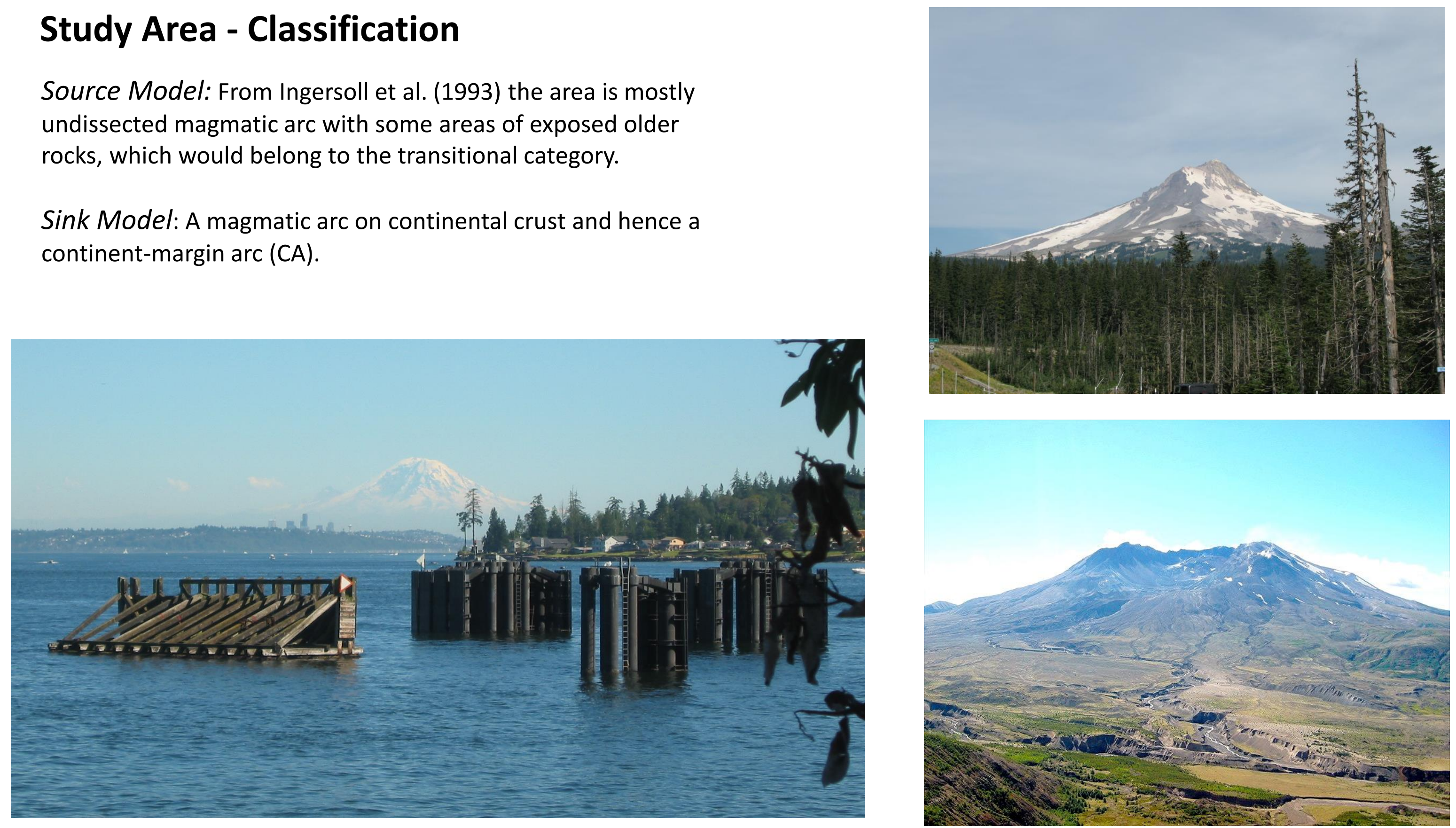


\section{Petrography}

The sands comprise plagioclase and lithic fragments with some pyroxeneamphibole-biotite grains. Quartz and K-feldspar are almost entirely absent.
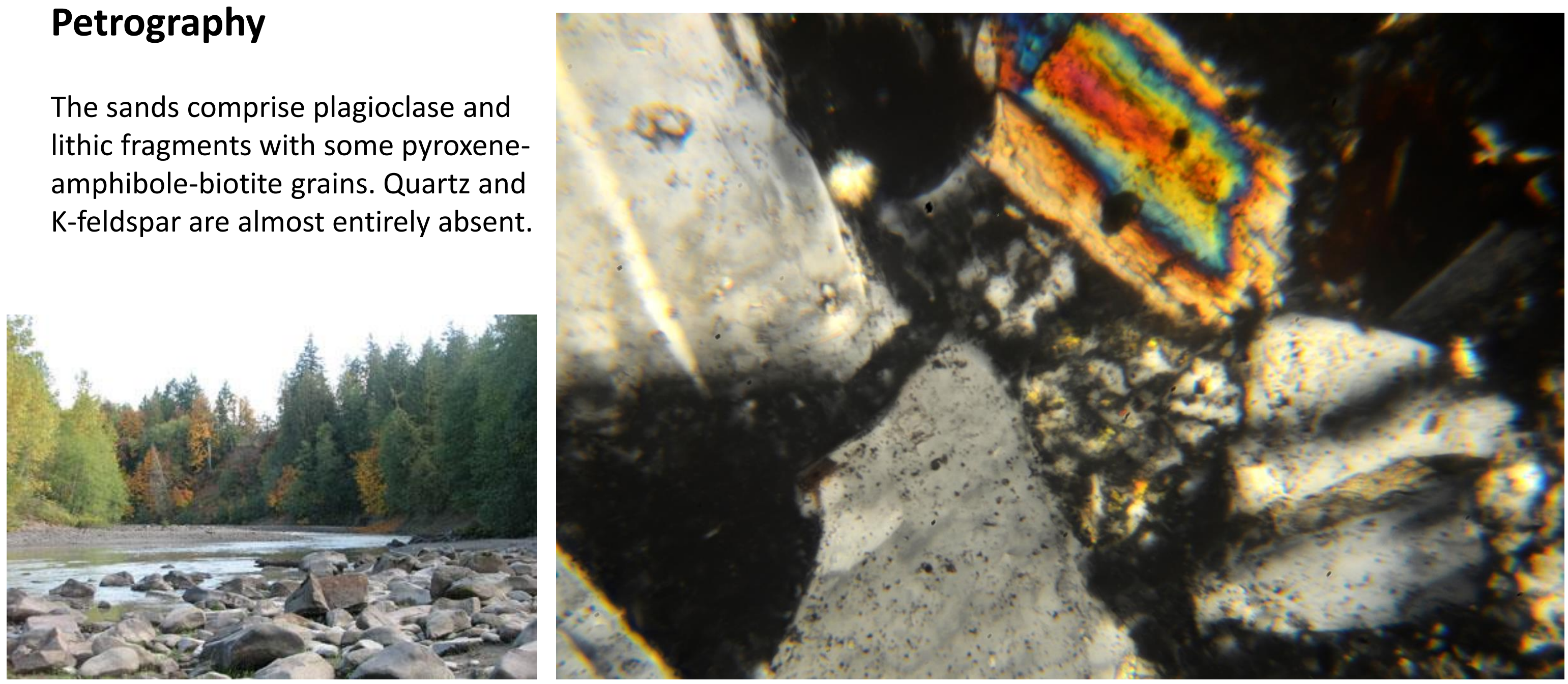


\section{Petrography - lithic fragments}
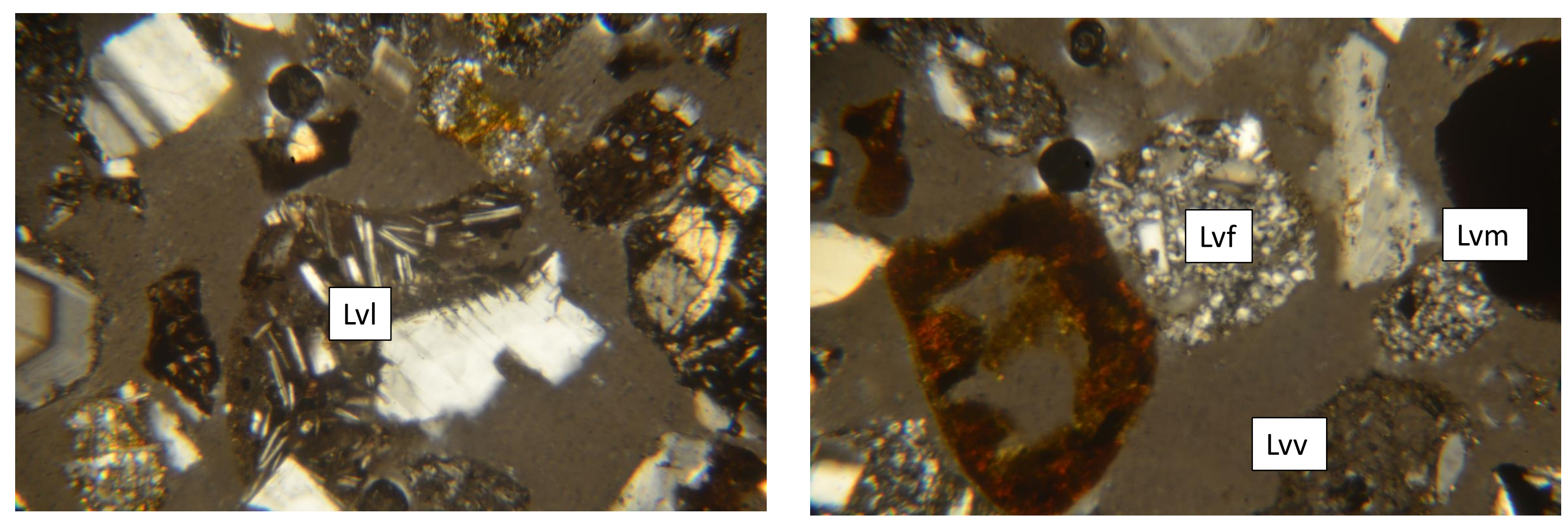

Can we add specificity to our models by including subvarieties? Here we see in partially crossed nicols lathwork (LVI), felsitic (Lvf) and microlitic (Lvm) lithic fragments and some glassy grains with very weak birefringence - vitrics (Lvv). 


\section{Petrography: QFL Triangles}
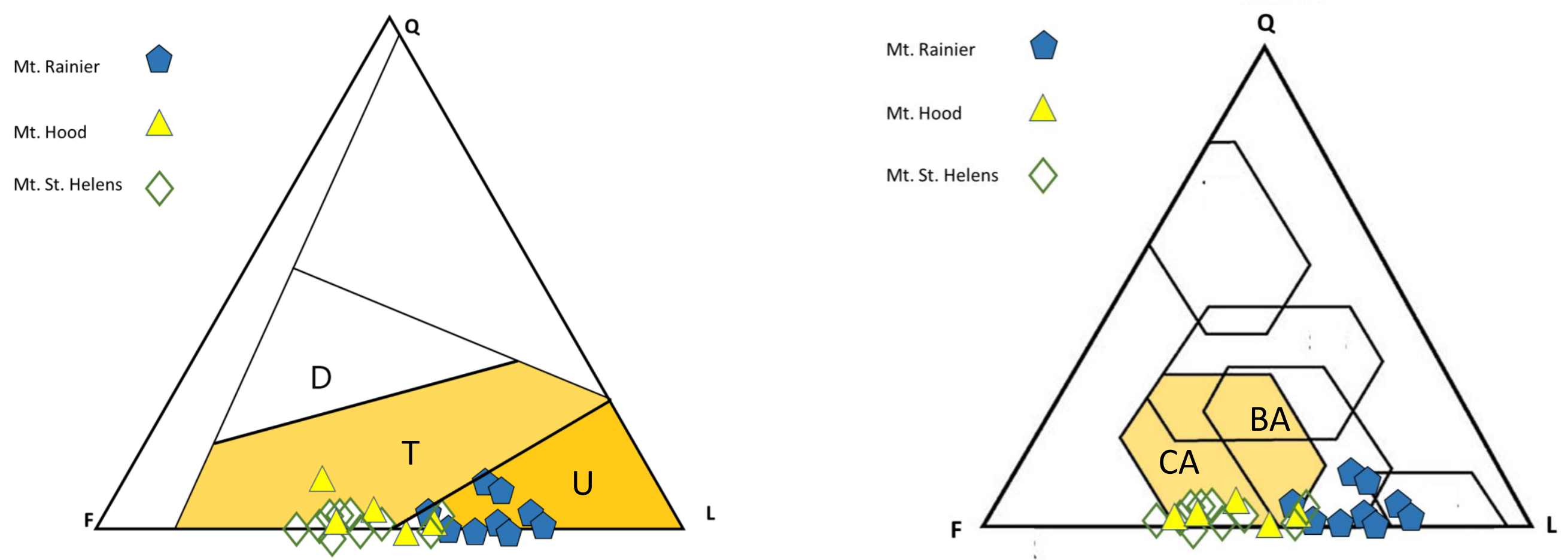

In QFL space, the samples from all three volcanoes cluster along the feldspar-lithics margin. Rainier samples are distinct, but Hood and St Helens overlap completely; the samples plot in multiple tectonic sub-categories in both schemes, transitional $(T)$ and undissected arc $(U)$ or continental arc (CA) and island-arc back arc (BA) in the other. 


\section{Petrography: More on QFL triangles}

The overlap on the Sink triangle is bothersome, because there is no confusion between island arcs and continental arcs. On the source triangle it is conceivable that Rainier, being so much larger, completely covers up any older rocks, whereas Hood and St Helens do not and so fall in the more dissected field, despite being the same age or even younger.

\section{Petrography: Lithic types triangles}

Can we gain more insight from other petrographic variables? All three volcanoes produce lithic grains that cover most of the range of variation on lithic category triangles.

Doesn't look like a good discriminator

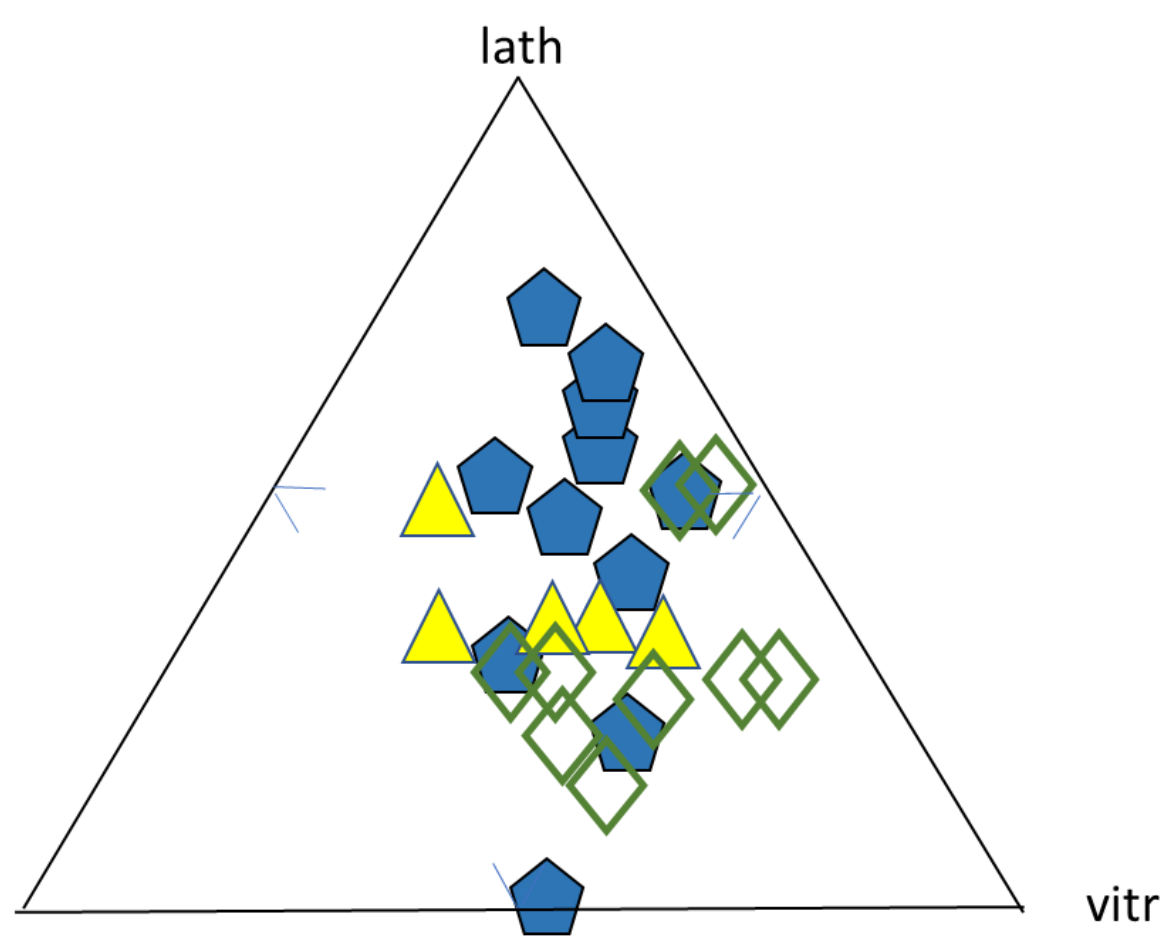




\section{Petrography: log-transformed plots}

The statistical limitations of the petrographic triangles can be mitigated by making the three variables into two ratios and plotting the natural logs (Weltje 2002, 2006). Here we show the distribution of values for the set of arcrelated deep-sea sands from Valloni \& Maynard 1981 and Marsaglia \& Ingersoll 1992. SS not shown for simplicity.

\section{ANOVA: post-hoc Tukey test of significance}

\begin{tabular}{lcccc} 
& Ln Q/L & Ln F/L & $\begin{array}{l}\text { Ln fels/ } \\
\text { micro }\end{array}$ & $\begin{array}{l}\text { Ln lath/ } \\
\text { micro }\end{array}$ \\
\hline Q.05 & 3.91 & 3.91 & 3.94 & 3.94 \\
Q.01 & 4.69 & 4.69 & 4.75 & 4.75 \\
\hline BA-CA & 1.04 & 2.37 & $(4.42)$ & 0.72 \\
BA-FA & 8.89 & $(4.31)$ & 1.07 & 1.55 \\
BA-SS & 9.21 & 7.14 & 3.89 & 2.77 \\
CA-FA & 9.93 & 6.68 & 1.15 & 5.41 \\
CA-SS & 8.17 & 4.77 & 2.38 & 3.50 \\
FA-SS & 18.1 & 11.5 & 8.53 & $(4.32)$
\end{tabular}

Values in red indicate means are not distinct at $95 \%$ Level; values in parenthesis at $99 \%$

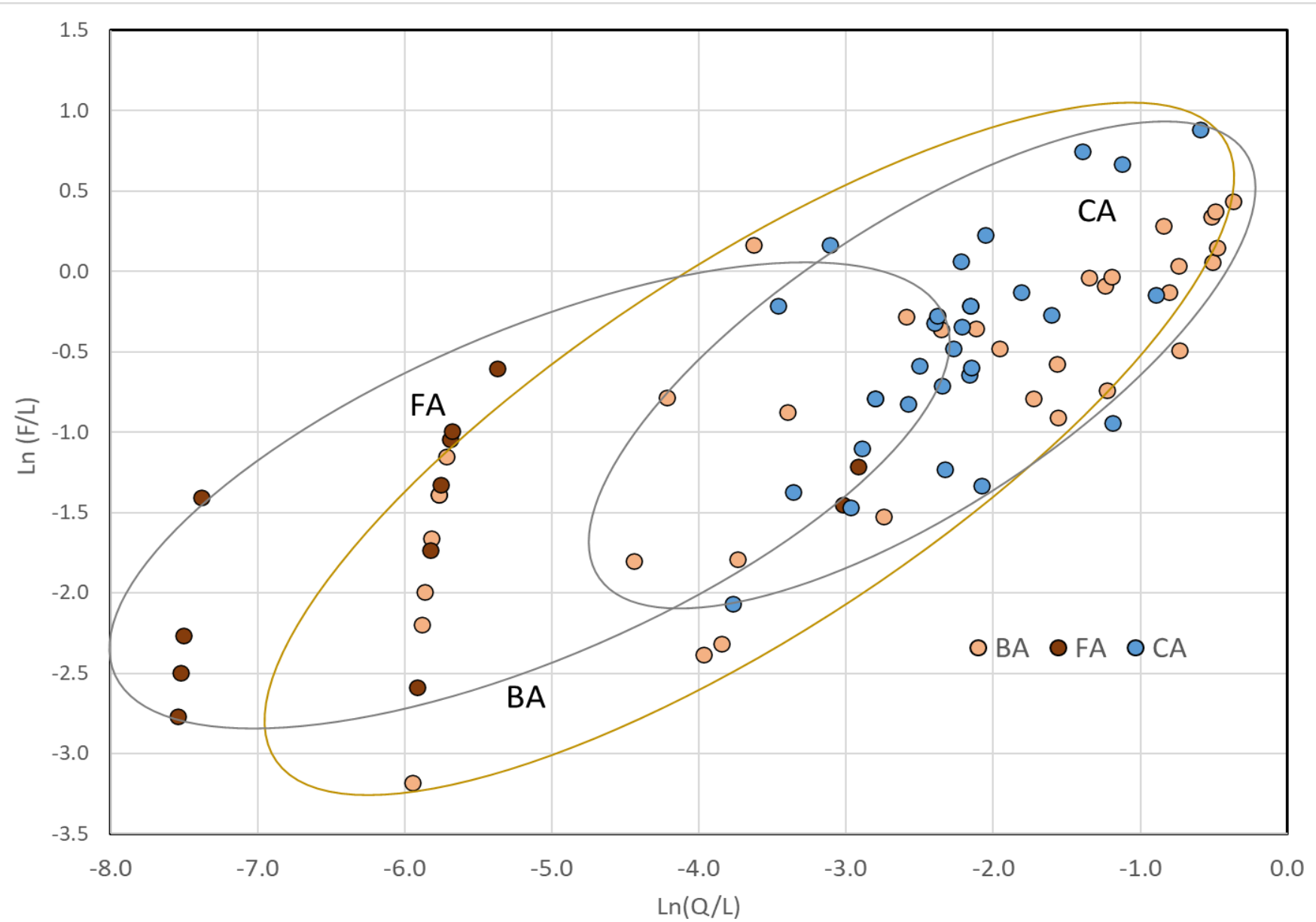




\section{Petrography: log-transformed plots}

\section{ANOVA: post-hoc Tukey test of}

significance

\begin{tabular}{llccc} 
& Ln Q/L & Ln F/L & $\begin{array}{l}\text { Ln fels/ } \\
\text { micro }\end{array}$ & $\begin{array}{l}\text { Ln lath/ } \\
\text { micro }\end{array}$ \\
\hline Q.05 & 3.91 & 3.91 & 3.94 & 3.94 \\
Q.01 & 4.69 & 4.69 & 4.75 & 4.75 \\
\hline BA-CA & 1.04 & 2.37 & $(4.42)$ & 0.72 \\
BA-FA & 8.89 & $(4.31)$ & 1.07 & 1.55 \\
BA-SS & 9.21 & 7.14 & 3.89 & 2.77 \\
CA-FA & 9.93 & 6.68 & 1.15 & 5.41 \\
CA-SS & 8.17 & 4.77 & 2.38 & 3.50 \\
FA-SS & 18.1 & 11.5 & 8.53 & $(4.32)$
\end{tabular}

PEP guiding

field trip in $S$ Illinois

A simple test of degree of separation of the tectonic categories can be made using ANOVA followed by the Tukey test, if any means are significantly different, to determine which pairs in the ANOVA test are distinct.

We see that the BA and CA categories have equivalent means for both $Q / L$ and $F / L$ at the $95 \%$ level. The other pairs have discrete means at the $95 \%$ level but the BA-FA pair is not separate at the $99 \%$ level. The ratios of lithic types fail in most cases to provide a distinction. (For a similar analysis of the Dickinson approach see Weltje 2006) 


\section{Petrography: log-transformed plots-beta}

Because the continent arc (CA) and island-arc back arc (BA) are indistinguishable, let's combine those and include the strike-slip (SS) category.

The three remaining fields with independent mean values still overlap considerably:

FA overlaps onto BA-CA by $33 \%$

SS overlaps onto BA-CA by $27 \%$

TE (not shown) overlaps $31 \%$ onto SS; means still distinct at $95 \%$ level.

ANOVA: post-hoc Tukey test of significance

$\operatorname{Ln} Q / L$

$\operatorname{Ln} F / L$

\begin{tabular}{ccc} 
Q.05 $=$ & 3.38 & 3.38 \\
$\mathrm{Q} .01=$ & 4.24 & 4.24 \\
\hline $\mathrm{TE}-\mathrm{SS}$ & 6.40 & $(3.88)$ \\
\hline
\end{tabular}

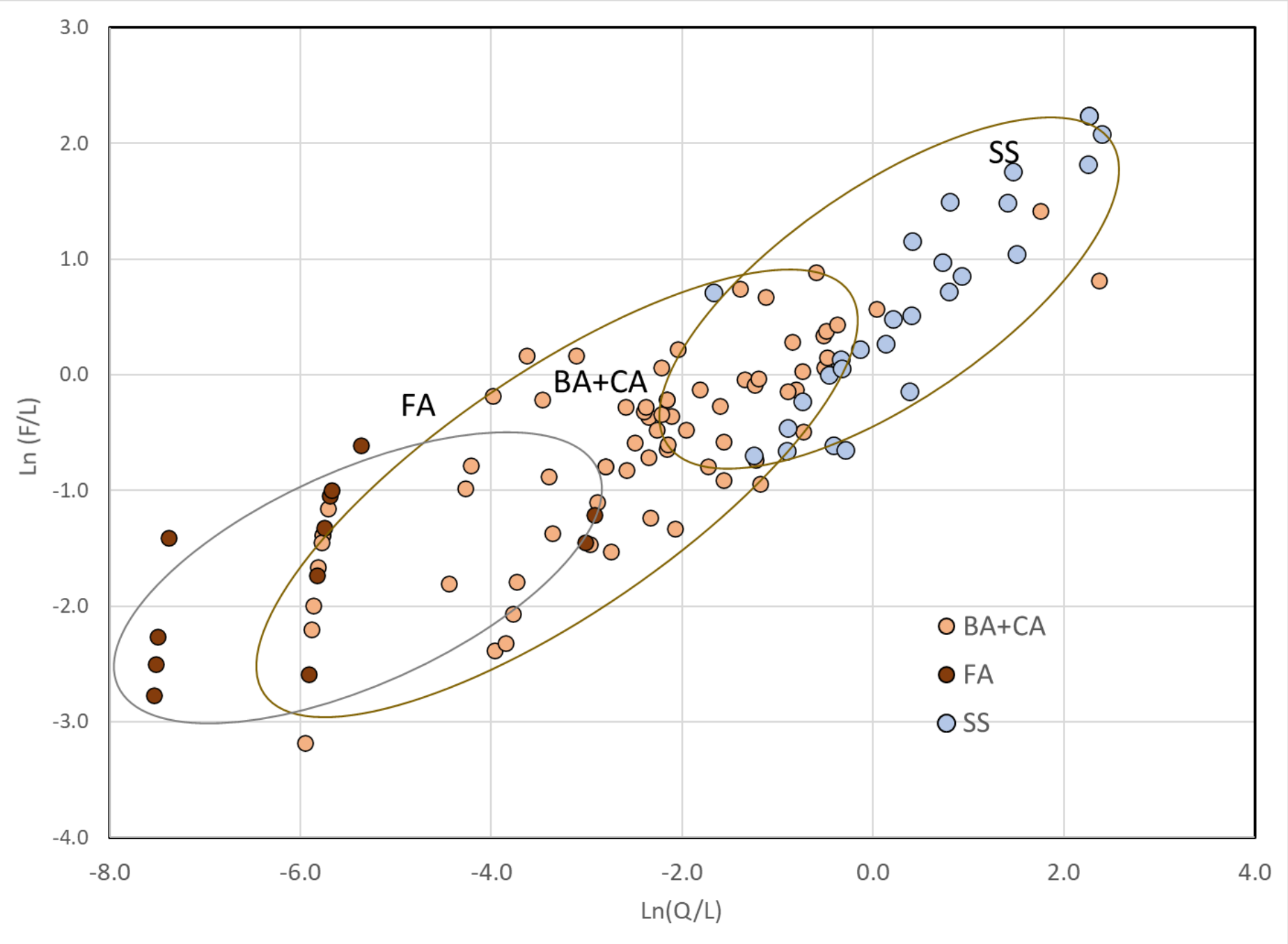




\section{Petrography: conclusions from deep-sea sands record}

The ANOVA results indicate that

- Trailing-edge (TE) sands overlap strike-slip sands (SS) about 1/3 but mean values are significantly different at $95 \%$.

- Sands on the back arc side of island arcs (BA) and continental arc sands (CA) overlap almost completely.

- SS sands and FA sands each overlap the BA+CA category about $1 / 3$, but have statistically different means.

Well, that's not very encouraging. We have about a $1 / 3$ chance of being wrong for any individual sample. A batting average of 0.67 might be great in baseball, but not so good for us.

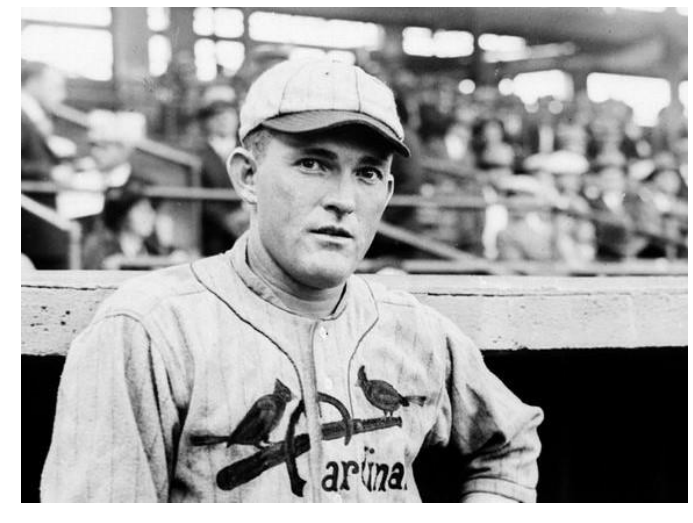

Rogers Hornsby batted 0.424 in 1922 for St. Louis. Lifetime 0.321

PEP was a dedicated baseball player in his earlier years (pitcher) but I don't know his liftetime batting average 


\section{Petrography: The Cascade sample set 1}

How well do our stream sands correspond to their tectonic setting?

Hmmm! They are obviously arcrelated, but it would be hard to identify what subcategory they should be assigned to.

ANOVA: post-hoc Tukey test of significance

\begin{tabular}{lcccc} 
& Ln Q/L & Ln F/L & $\begin{array}{l}\text { Ln fels/ } \\
\text { micro }\end{array}$ & $\begin{array}{l}\text { Ln lath/ } \\
\text { micro }\end{array}$ \\
\hline Q.05 & 3.91 & 3.91 & 3.94 & 3.94 \\
Q.01 & 4.69 & 4.69 & 4.75 & 4.75 \\
\hline BA-Cas & 3.06 & 2.59 & 4.85 & 5.41 \\
CA-Cas & $(4.10)$ & 0.22 & 3.34 & 6.13 \\
FA-Cas & 5.83 & 6.9 & $(4.49)$ & 6.96 \\
SS-Cas & 12.3 & $(4.55)$ & 0.96 & 2.63
\end{tabular}

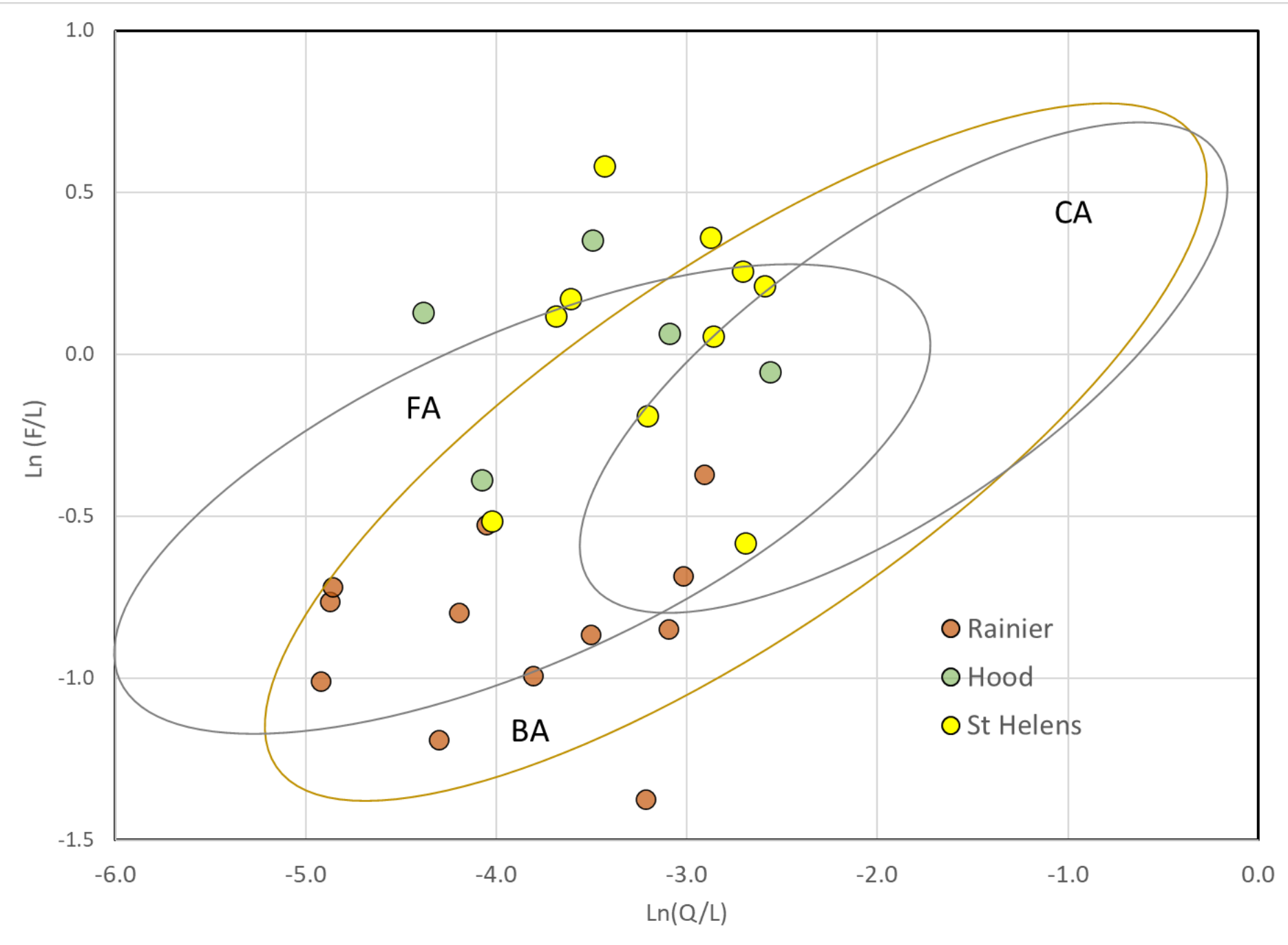




\section{Petrography: The Cascade sample set 2}

They do seem to match the offshore sands fairly well (if we regard the BA and CA categories as indistinguishable), which confirms the assertion of Ingersoll et al. (1993) that arc-related sand compositions are scale-independent.

ANOVA: post-hoc Tukey test of significance

\begin{tabular}{lrrrc} 
& Ln Q/L & Ln F/L & $\begin{array}{l}\text { Lnfels/ } \\
\text { micro }\end{array}$ & $\begin{array}{l}\text { Ln lath/ } \\
\text { micro }\end{array}$ \\
\hline Q.05 & 3.91 & 3.91 & 3.94 & 3.94 \\
Q.01 & 4.69 & 4.69 & 4.75 & 4.75 \\
\hline R-H+SH & 1.66 & $(4.28)$ & 3.16 & 0.67
\end{tabular}

We do see that the Rainier samples, although very similar to the others along the $Q / L$ axis, are almost completely separate along the $F / L$ axis. The statistical analysis confirms this, but note the difference is not significant at the $99 \%$ level, and other parameters fail to make a distinction.

We conclude, as have others, that the broad tectonic categories can be recognized in the sands, but not the subcategories.

There is some hope, however, for recognizing relative changes. For example, a shift from Rainierdominated to St Helens-dominated detritus in the streams running between them should be recognizable. 
The Andean continental arc has significant gaps that lack volcanic activity in the modern.

That is, the western margin of South America is not a homogeneous setting, but comprises alternating magmatic arc and recycled orogen provenance settings or alternating continental arc and "strike-slip" basin settings.

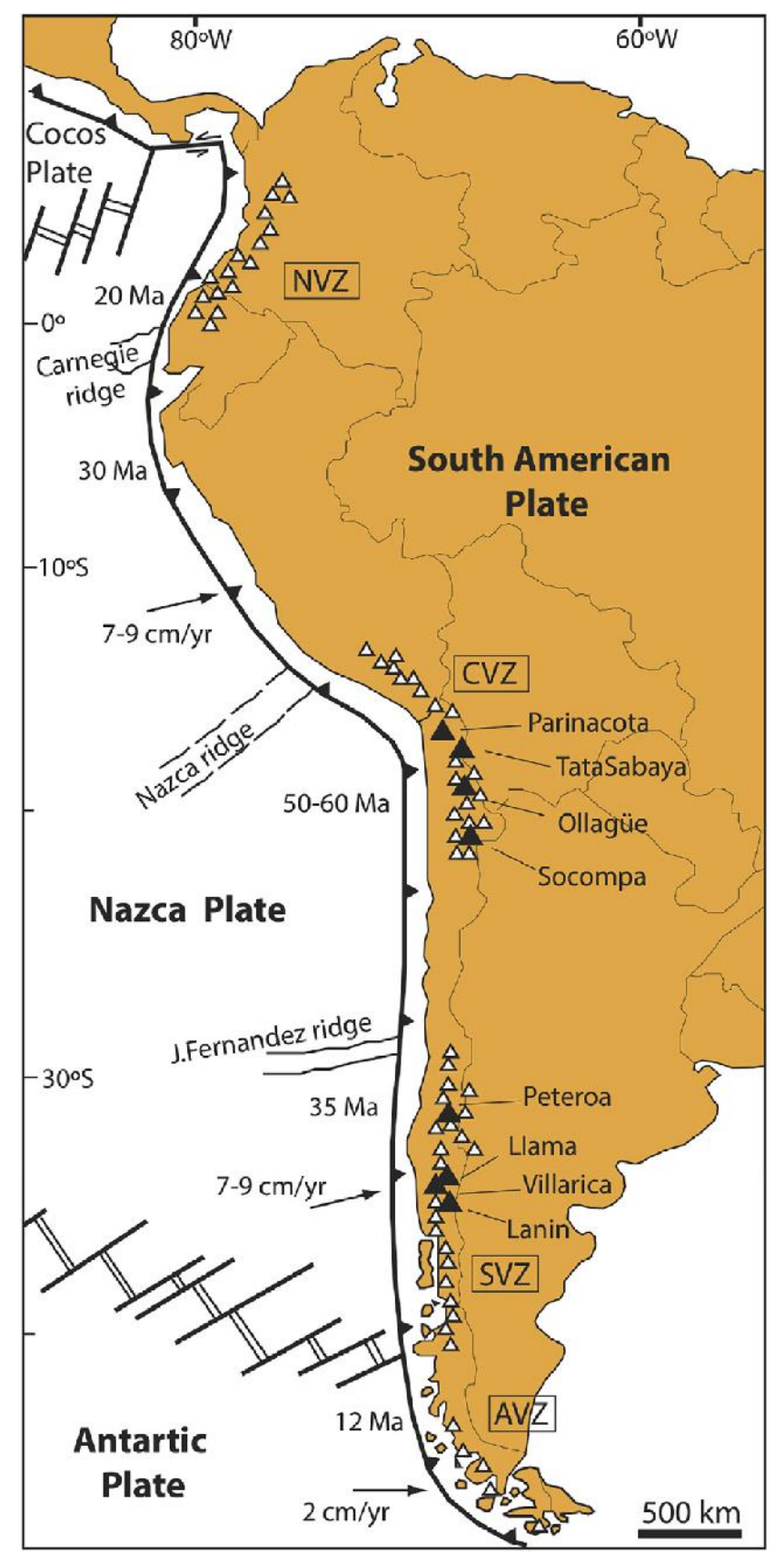




\section{Petrography: An example from a different a arc continued}

The gaps in the volcanic arc correspond to changes in the F/L ratio of offshore sands, except for the segment adjacent to the Atacama Desert, which has no sand (Yerino \& Maynard, 1984).

The $\mathrm{F} / \mathrm{L}$ ratio ranges from 0.5 to 5.5 for what would seem to be a single environment, but the relative changes in the deep-sea sands alert us to significant changes along the arc.

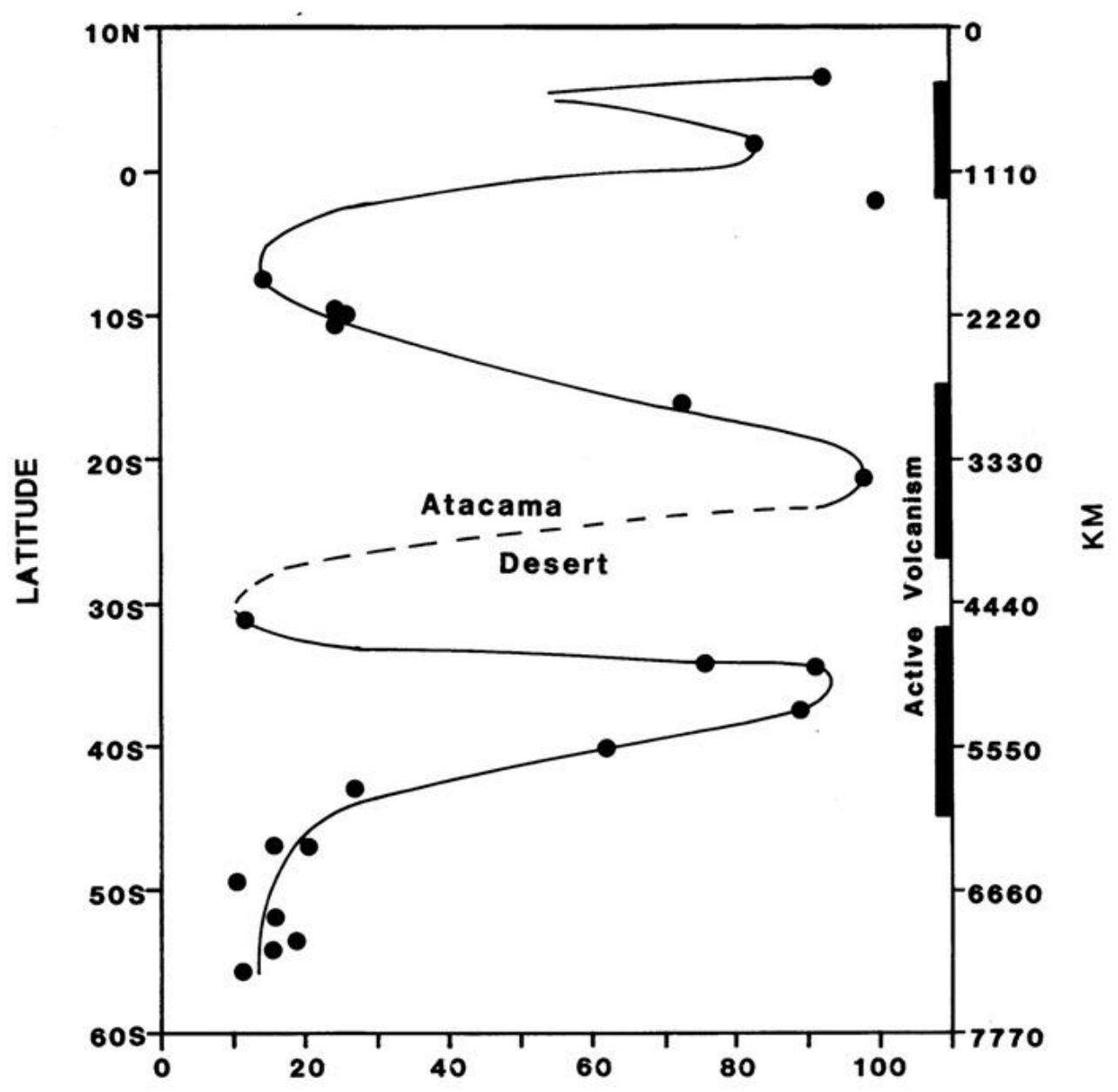

\% LithIC GRAINS 


\section{Geochemistry 1: Whole-rock}

We have yet to discover a set of "conventional" wholerock parameters that provides effective discrimination among the volcanoes.

From the deep-sea sands, Th/Sc v $\varepsilon_{\text {Nd }}$ would be promising, or some of the REE ratios (see McLennan et al. 1990)

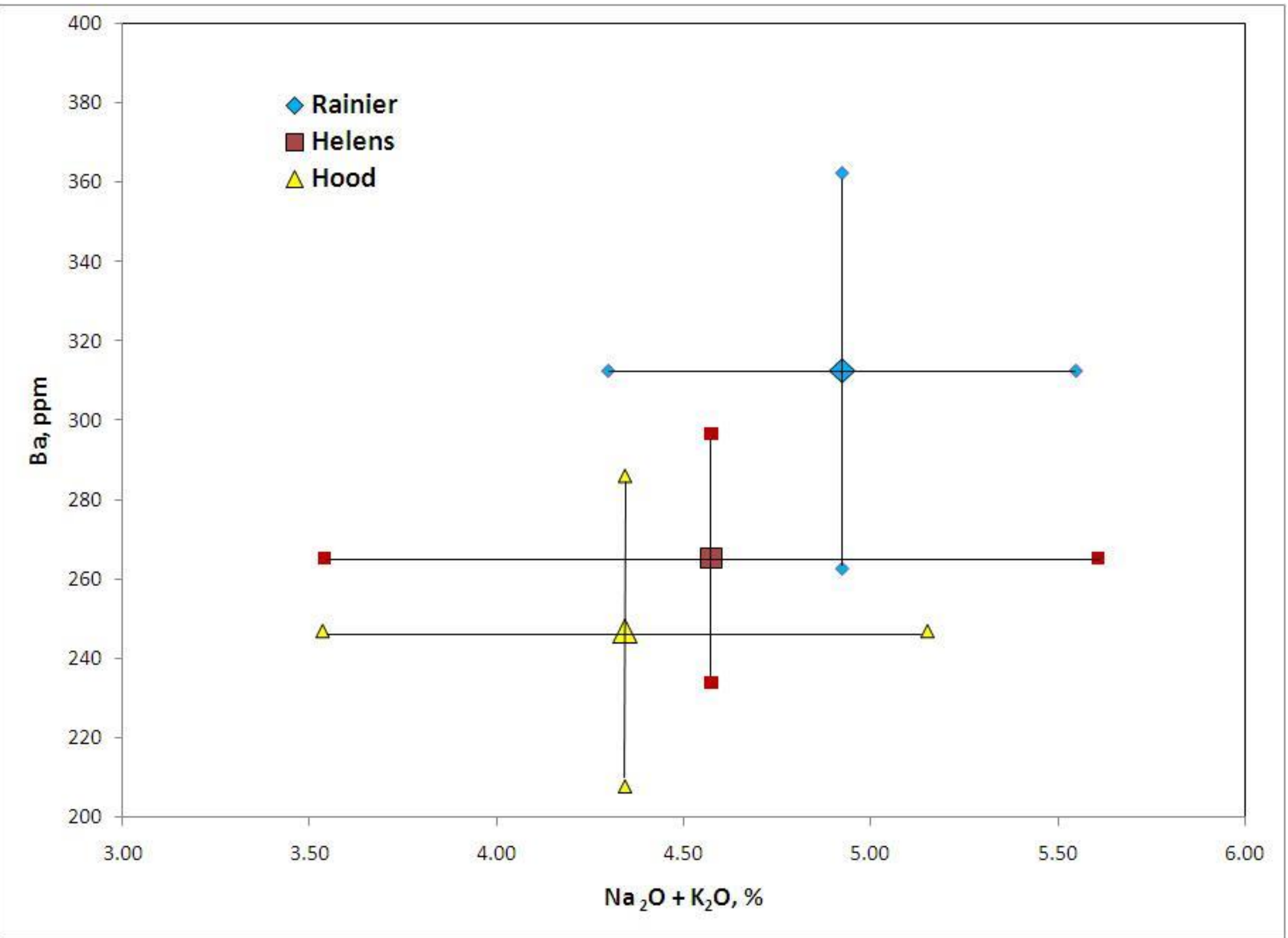


Geochemistry 2: Mineral chemistry - feldspars

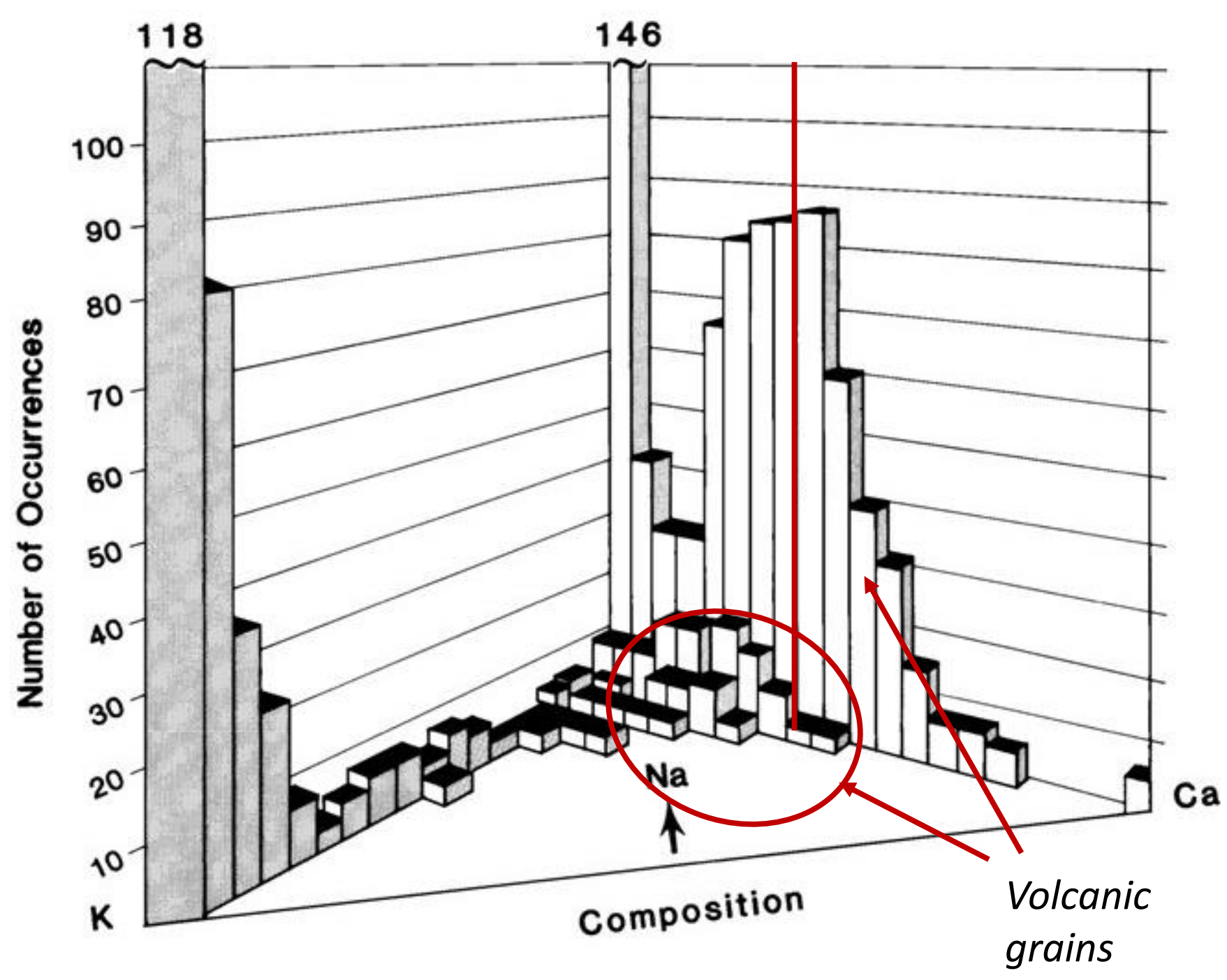

A better potential exists for single-mineral studies. Shown here is microprobe data for the deep-sea sands, which still show the complete overlap of the CA and BA categories. Not so good, but unequivocally volcanic grains can be identified. (Maynard, 1984)

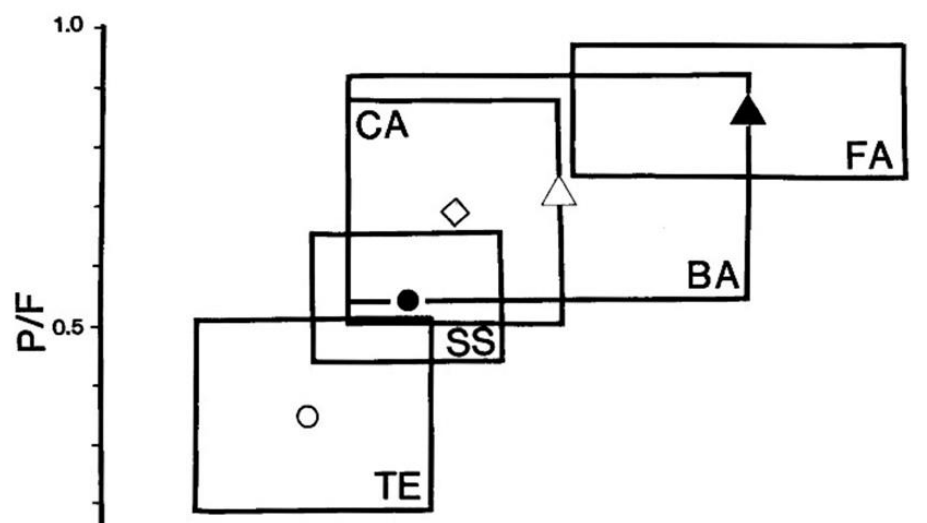

$\%$ An 


\section{Geochemistry 2: Mineral chemistry - zircons}

The future of provenance studies seems lie mostly in work on isotopes of single mineral grains like zircons.

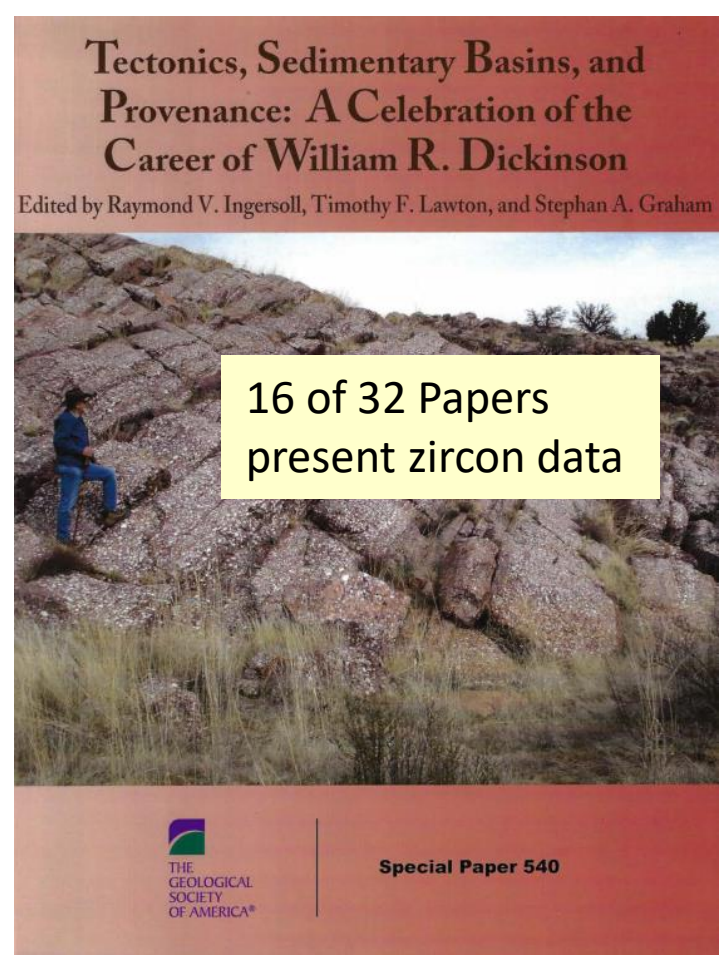

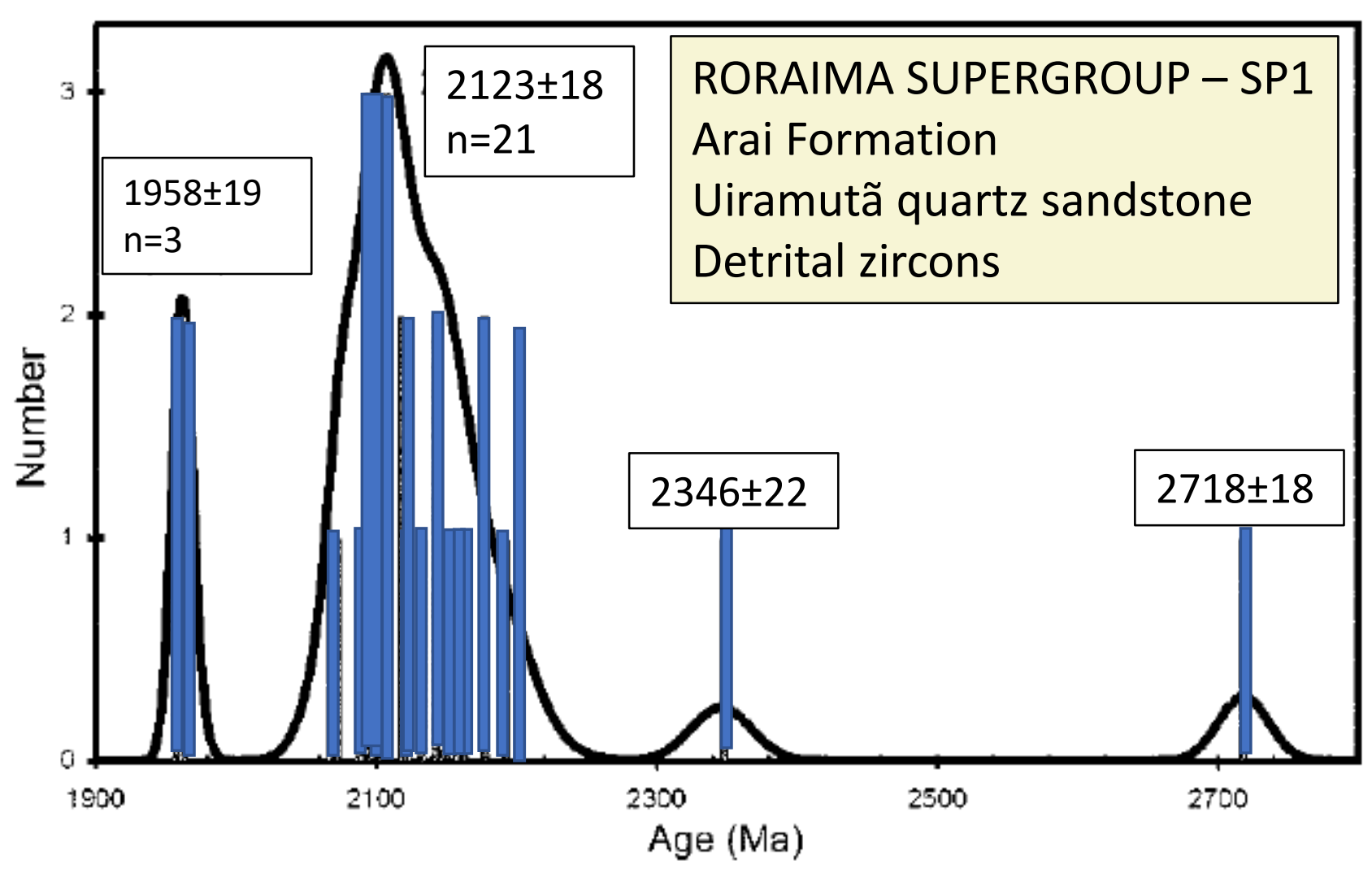

Source ages for the Roraima quartzites in Brazil, Santos et al. 2003. From Paul's work with the federal university in Rio Grande do Sul. 


\section{References}

Ingersoll, R.V., Kretchmer, A.G. and Valles, P.K., 1993. The effect of sampling scale on actualistic sandstone petrofacies. Sedimentology, 40(5), pp.937-953.

Marsaglia, K.M. and Ingersoll, R.V., 1992. Compositional trends in arc-related, deep-marine sand and sandstone: a reassessment of magmatic-arc provenance. Geological Society of America Bulletin, 104(12), pp.1637-1649.

Maynard, J.B., 1984. Composition of plagioclase feldspar in modern deep-sea sands: relationship to tectonic setting. Sedimentology, 31(4), pp.493-501.

McLennan, S.M., Taylor, S.R., McCulloch, M.T. and Maynard, J.B., 1990. Geochemical and Nd $\square$ Sr isotopic composition of deep-sea turbidites: crustal evolution and plate tectonic associations. Geochimica et Cosmochimica Acta, 54(7), pp.2015-2050.

Santos, J.O.S., Potter, P.E., Reis, N.J., Hartmann, L.A., Fletcher, I.R. and McNaughton, N.J., 2003. Age, source, and regional stratigraphy of the Roraima Supergroup and Roraima-like outliers in northern South America based on U-Pb geochronology. Geological Society of America Bulletin, 115(3), pp.331-348.

Weltje, G.J., 2002. Quantitative analysis of detrital modes: statistically rigorous confidence regions in ternary diagrams and their use in sedimentary petrology. Earth-Science Reviews, 57(3-4), pp.211-253.

Weltje, G.J., 2006. Ternary sandstone composition and provenance: an evaluation of the 'Dickinson model'. Geological Society, London, Special Publications, 264(1), pp.79-99.

Valloni, R. and Maynard, J.B., 1981. Detrital modes of recent deep-sea sands and their relation to tectonic setting: a first approximation. Sedimentology, 28(1), pp.75-83. 